\title{
Influence of speed of filling and draw-off to the filtration regime of Earth-fill dam
}

\author{
Shahnoza Djabbarova ${ }^{1 *}$, Turovoy Muslimov ${ }^{1}$, Shahriddin Boymatov ${ }^{2}$ \\ ${ }^{1}$ Tashkent Institute of Irrigation and Agricultural Mechanization Engineers, Tashkent, Uzbekistan \\ ${ }^{2}$ Tashkent institute of Architecture and Civil Engineering, Tashkent, Uzbekistan
}

\begin{abstract}
To use and manage water resources and carry out protection measures from the destructive effect of water flow, water reservoir hydrosystem construction has greatly developed. The article presents the results of field studies to determine unsteady filtration in the Earth-fill dam core. In the research process, static data from literature review, field study data, and theoretical processing of research results were used. Numerical data processing was carried out with methods of mathematical statistics, and the graphical part was done using Microsoft Excel. Calculations were carried out for phreatic line curve in the core of Earth-fill dam under unsteady filtration for various velocities of reservoir draw-off and water yield coefficient. At the same time, it has been established that the increase of velocity and time of water reservoir draw-off leads to the increase of filtration pressure, and the decrease of water yield factor leads to the decrease of filtration pressure. The increase of filtration pressure, in turn, contributes to the increase of the intensity of unsteady filtration of the Earth-fill dam core.
\end{abstract}

\section{Introduction}

To use and manage water resources and carry out protection measures from the destructive effect of water flow, water reservoir hydrosystem construction has greatly developed. Following the development of water reservoirs, dangerous phenomena began to occur, which are related to shortcomings in the design, construction, operation, and imperfection of structural elements that make up hydrosystems. Construction of water reservoir hydrosystems has increased in the past century, and the potential threat from them has increased respectively. When designing and constructing hydrosystems, one of the most important tasks is to provide their safety. In this regard, increasing the operational reliability of hydrotechnical structures, providing their strength and stability, are of particular importance. Great attention is being paid to purposeful research works devoted to theoretical and experimental studies of unsteady filtration in earthfill dams and their influence on the stability of the earthfill dam upper slope. In this regard, one of the important tasks is to improve methods of unsteady filtration design in the body and bank

*Corresponding author: shdjabbarova1985@mail.ru 
massifs of earthfill dams, determining the influence of unsteady filtration on the carrying capacity of water passage structures [2-3], [5-6], [21-22].

\section{Methods}

In the research process, static data from literature review, field study data, and theoretical processing of research results were used. Besides, numerical processing of data was carried out with methods of mathematical statistics, and the graphical part was done using Microsoft Excel.

\section{Results and Discussion}

Design velocity of water reservoir filling must be about $0.3-0.5 \mathrm{~m} /$ day, and reservoir water level draw-off velocity must be $0.3 \mathrm{~m} /$ day. The analysis of field observations gave the following:

- violations in filling and draw-off regime of the water reservoir (in 2009 it took place about 10 times);

- during the year 2010 at a mean velocity of water reservoir filling velocity of 0.13 $\mathrm{m} /$ day, the maximal velocity of water reservoir filling velocity was $1.73 \mathrm{~m} /$ day, while allowable velocity was $0.5 \mathrm{~m} /$ day;

- mean velocity of water reservoir draw-off was $0.42 \mathrm{~m} /$ day, and the maximal velocity of water reservoir draw-off was $0.73-1.5 \mathrm{~m} /$ day in 2010; at this intolerable velocity, water reservoir draw-off lasted 10 days. That mostly happened due to the violation of the regime of water reservoir operation without accounting for the carrying capacity of spillway structures.

Calculations were carried out using V.M.Shestakov's method [1] with the following boundary conditions and assumptions: the core is considered to be a homogeneous Earthfill dam erected of loamy clay soil with the coefficient of filtration $\mathrm{k}_{\mathrm{ya}}=0.001 \mathrm{~m} /$ day.

- water level at the head race is taken equal to $960.0 \mathrm{~m}$;

- it is assumed that the water level at the upper prism and transition zones will decrease simultaneously with the water level at the head race;

- phreatic line position was determined for steady filtration at water level decrease time at the head race of $\mathrm{t}=0$.

Phreatic line position after time $t$ is determined using the following relationship:

$$
y_{t}=\left\{y^{2}-\vartheta \cdot t\left[h_{1}+h_{t} \frac{m_{1} \cdot\left(h_{1}^{2}-h_{2}^{2}\right)}{L}\right] \cdot\left[F_{(\lambda, n)}-\frac{x+m_{1} \cdot \vartheta \cdot t}{L+m_{1} \cdot \vartheta \cdot t} \cdot F_{(L, n)}\right]\right\}^{1 / 2}
$$

where $v$ is mean velocity of water level decrease at head race;

$$
h_{t}=h_{1}-\vartheta \cdot t
$$

$$
\left.\begin{array}{l}
F_{(\lambda, n)} \\
F_{(L, n)}
\end{array}\right\}
$$


- functions, determined from plots [1],

where:

$$
\begin{gathered}
\lambda=n \cdot \frac{x}{2 \sqrt{a \cdot t}} ; \\
\lambda_{L}=n \cdot \frac{L}{2 \sqrt{a \cdot t}} ; \\
n=\frac{m_{1} \cdot \vartheta \cdot t}{2 \sqrt{a \cdot t}} ; \\
a=\frac{k_{r} \cdot h_{1}+h_{t}}{2 \mu_{r}} ;
\end{gathered}
$$

Calculations are carried out for design conditions with water draw-off velocities in hydrosystem $v=2.5$ and $5.0 \mathrm{~m} /$ day at times $\mathrm{t}=5,10,15,20,25,30$ days and water yield factor $\mu=0.028 ; 0.03 ; 0.032$. Calculations are given in Tables $1-4$.

Table 1. Phreatic line positions for draw-off velocity $\nu=5.0 \mathrm{~m} /$ day and water yield factor $\mu=0.028$

\begin{tabular}{|c|c|c|c|c|c|c|}
\hline $\mathrm{x}_{\mathrm{i}}$ & $\mathrm{y}(\mathrm{t}=5$ days $)$ & $\mathrm{y}(\mathrm{t}=10$ days $)$ & $\mathrm{y}(\mathrm{t}=15$ days $)$ & $\mathrm{y}(\mathrm{t}=20$ days $)$ & $\mathrm{y}(\mathrm{t}=25$ days $)$ & $\mathrm{y}(\mathrm{t}=30$ days $)$ \\
\hline 0 & 127.11 & 86.287 & 15.594 & 0.0 & 0.0 & 0.0 \\
\hline 5 & 133.86 & 113.08 & 92.88 & 75.242 & 59.606 & 47.356 \\
\hline 10 & 134.19 & 127.02 & 123.82 & 121.58 & 120.23 & 119.67 \\
\hline 20 & 127.23 & 124.76 & 123.18 & 122.63 & 122.44 & 122.52 \\
\hline 30 & 108.14 & 107.57 & 107.45 & 107.51 & 107.45 & 107.41 \\
\hline 40 & 96.586 & 96.481 & 96.484 & 96.484 & 96.484 & 96.484 \\
\hline 50 & 83.557 & 83.557 & 83.557 & 83.557 & 83.557 & 83.557 \\
\hline
\end{tabular}



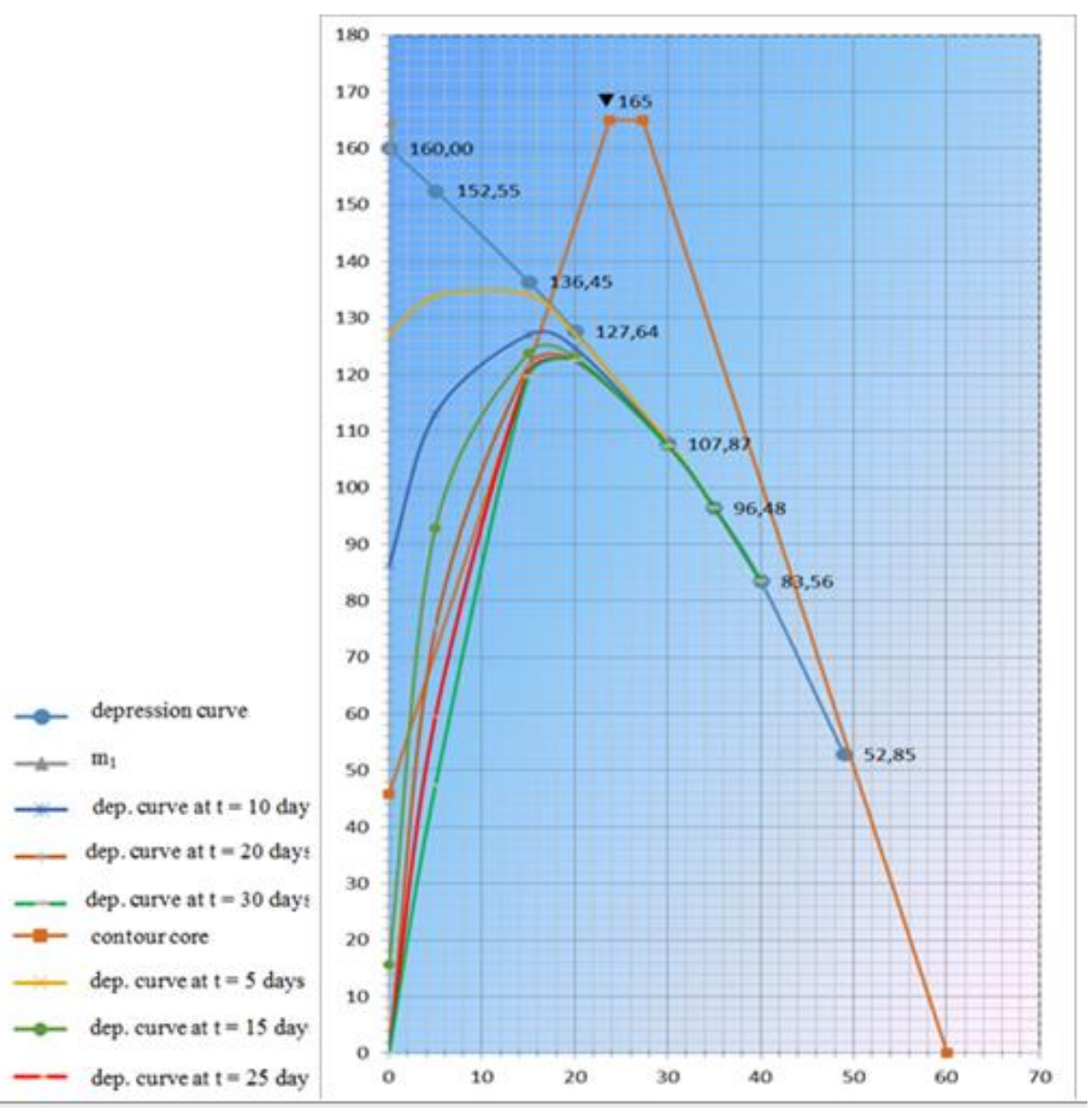

Fig. 1. Phreatic line for design condition for draw-off velocity $v=5.0 \mathrm{~m} /$ day and water yield factor $\mu=0.028$

Table 2. Phreatic line positions for draw-off velocity $\nu=2.5 \mathrm{~m} /$ day and water yield factor $\mu=0.030$

\begin{tabular}{|c|c|c|c|c|c|c|}
\hline $\mathrm{xi}$ & $\mathrm{y}(\mathrm{t}=5$ day $)$ & $\mathrm{y}(\mathrm{t}=10$ day $)$ & $\mathrm{y}(\mathrm{t}=15$ day $)$ & $\mathrm{y}(\mathrm{t}=20$ day $)$ & $\mathrm{y}(\mathrm{t}=25$ day $)$ & $\mathrm{y}(\mathrm{t}=30$ day $)$ \\
\hline 0 & 143.5 & 126.2 & 107.4 & 86.29 & 60.73 & 15.59 \\
\hline 5 & 140.5 & 128.9 & 115.6 & 100.8 & 84.06 & 63.88 \\
\hline 10 & 132 & 128.1 & 123 & 117.1 & 111.6 & 105.9 \\
\hline 20 & 124.7 & 122.2 & 118.1 & 113 & 108.9 & 104.5 \\
\hline 30 & 107.2 & 106.8 & 105.3 & 103.7 & 102.4 & 100.9 \\
\hline 40 & 96.26 & 96.14 & 96.06 & 94.88 & 94.23 & 93.48 \\
\hline 50 & 83.48 & 83.46 & 83.38 & 82.46 & 81.96 & 81.34 \\
\hline
\end{tabular}



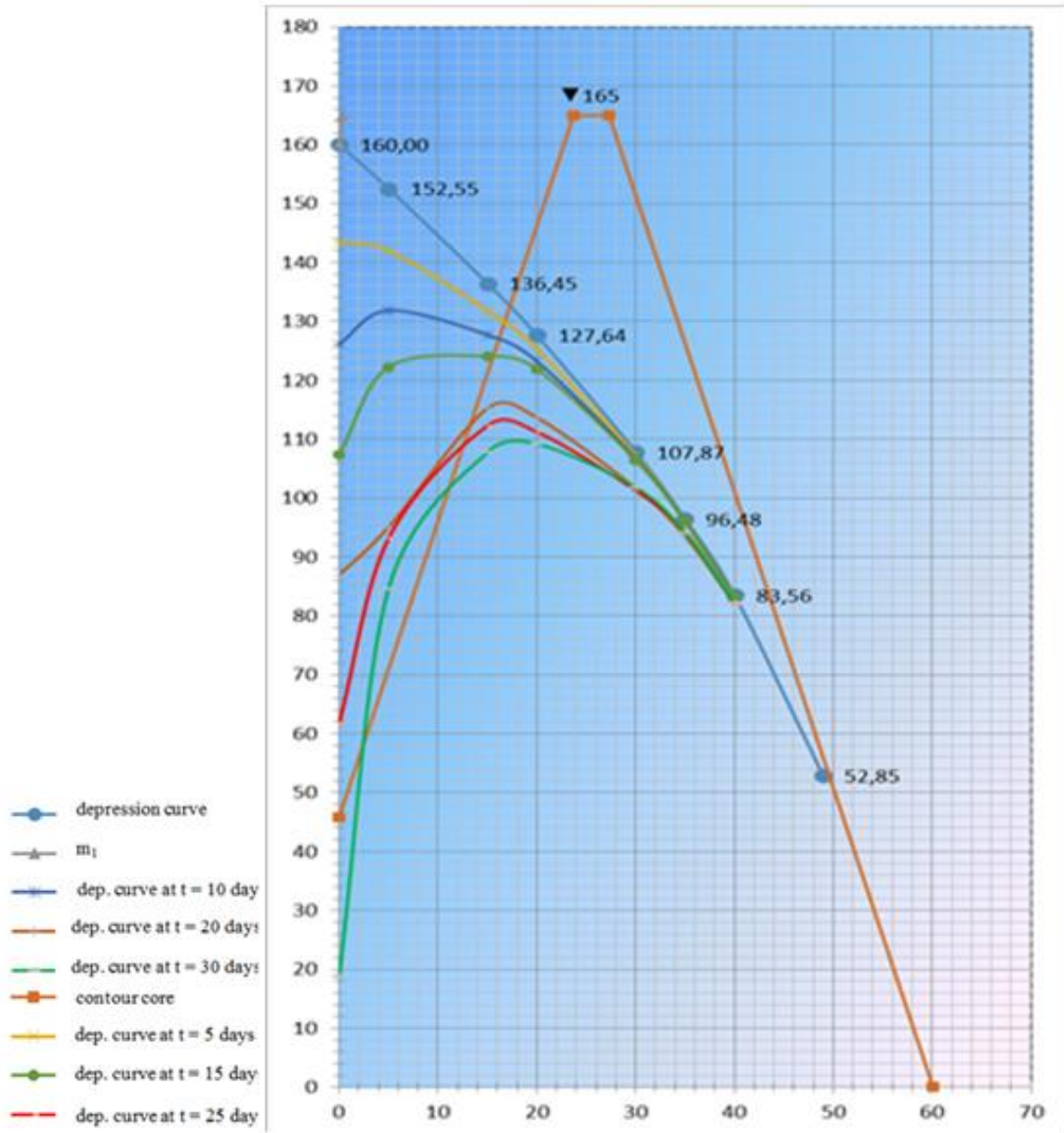

Fig. 2. Phreatic line for design condition for draw-off velocity $v=2.5 \mathrm{~m} /$ day and water yield factor $\mu=0.030$

Table 3. Phreatic line positions for draw-off velocity $\nu=5.0 \mathrm{~m} /$ day and water yield factor $\mu=0.030$

\begin{tabular}{|c|c|c|c|c|c|c|}
\hline $\mathrm{x}_{\mathrm{i}}$ & $\mathrm{y}(\mathrm{t}=5$ day $)$ & $\mathrm{y}(\mathrm{t}=10$ day $)$ & $\mathrm{y}(\mathrm{t}=15$ day $)$ & $\mathrm{y}(\mathrm{t}=20$ day $)$ & $\mathrm{y}(\mathrm{t}=25$ day $)$ & $\mathrm{y}(\mathrm{t}=30$ day $)$ \\
\hline 0 & 126.1 & 86.29 & 15.59 & 0.0 & 0.0 & 0.0 \\
\hline 5 & 132.4 & 114.3 & 96.89 & 72.03 & 43.84 & 0.0 \\
\hline 10 & 133.8 & 130.3 & 126.6 & 124.9 & 124 & 122.7 \\
\hline 20 & 126.9 & 125.6 & 125.4 & 124.8 & 124.8 & 124.6 \\
\hline 30 & 107.8 & 107.7 & 107.9 & 107.9 & 107.9 & 107.9 \\
\hline 40 & 96.48 & 96.47 & 96.48 & 96.48 & 96.48 & 96.48 \\
\hline 50 & 83.56 & 83.56 & 83.56 & 83.56 & 83.56 & 83.56 \\
\hline
\end{tabular}




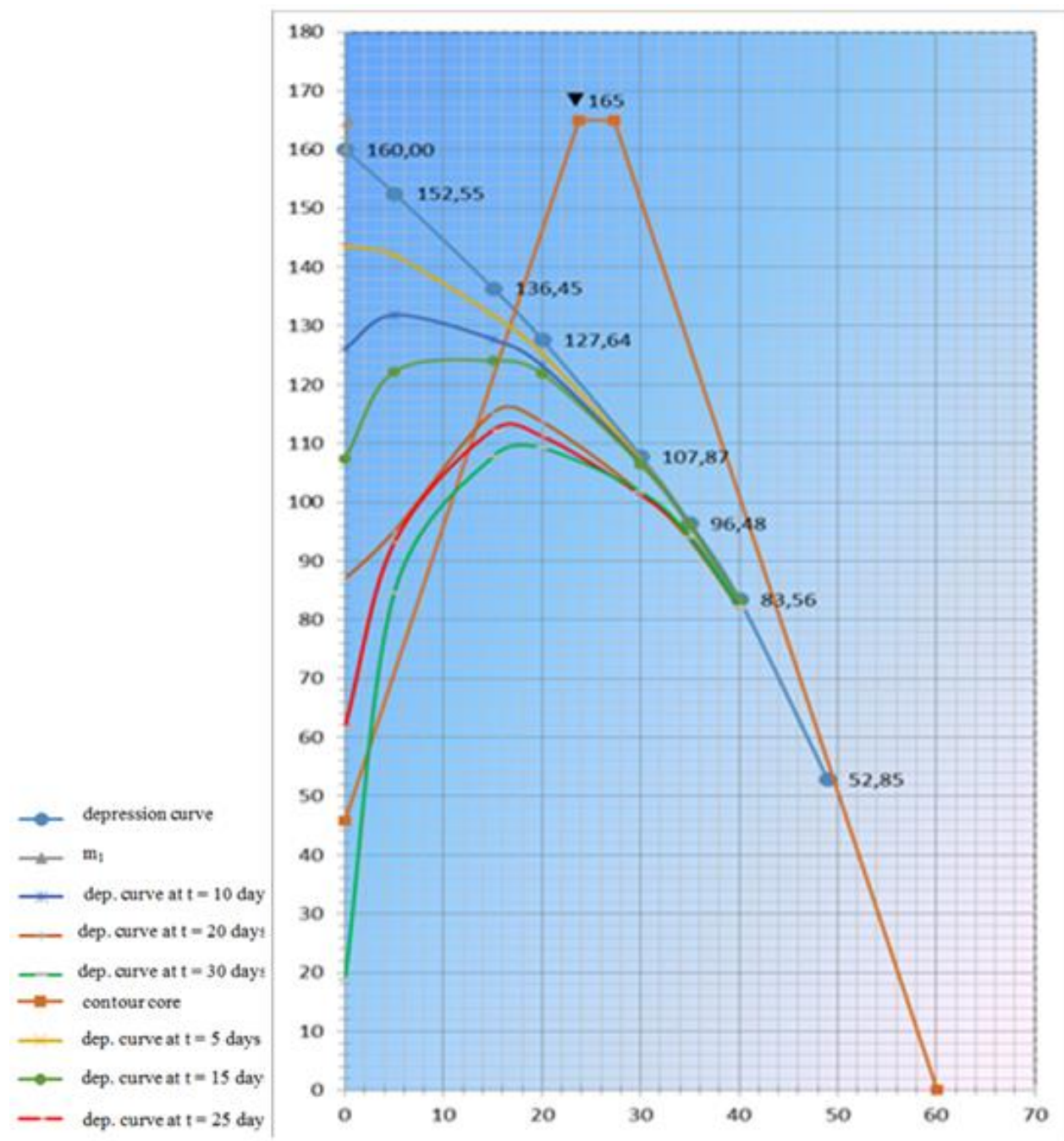

Fig. 3. Phreatic line for design condition for draw-off velocity $v=2.5 \mathrm{~m} /$ day and water yield factor $\mu=0.030$

Table 4. Phreatic line positions for draw-off velocity $v=3.5 \mathrm{~m} /$ day and water yield factor $\mu=0.032$

\begin{tabular}{|c|c|c|c|c|c|c|}
\hline $\mathrm{x}_{\mathrm{i}}$ & $\mathrm{y}(\mathrm{t}=5$ day $)$ & $\mathrm{y}(\mathrm{t}=10$ day $)$ & $\mathrm{y}(\mathrm{t}=15$ day $)$ & $\mathrm{y}(\mathrm{t}=20$ day $)$ & $\mathrm{y}(\mathrm{t}=25$ day $)$ & $\mathrm{y}(\mathrm{t}=30$ day $)$ \\
\hline 0 & 136.7 & 111.2 & 81.66 & 39.79 & 0.0 & 0.0 \\
\hline 5 & 135.2 & 118 & 105.6 & 86.69 & 64.16 & 45.26 \\
\hline 10 & 132.5 & 129.6 & 125.5 & 120.8 & 115.5 & 114.8 \\
\hline 20 & 126.2 & 124.1 & 123.3 & 121.6 & 119.9 & 118 \\
\hline 30 & 107.6 & 107.1 & 107 & 106.5 & 106.3 & 106.4 \\
\hline 40 & 96.43 & 96.31 & 96.13 & 95.87 & 95.76 & 95.88 \\
\hline 50 & 83.54 & 83.49 & 83.46 & 83.43 & 83.4 & 83.56 \\
\hline
\end{tabular}




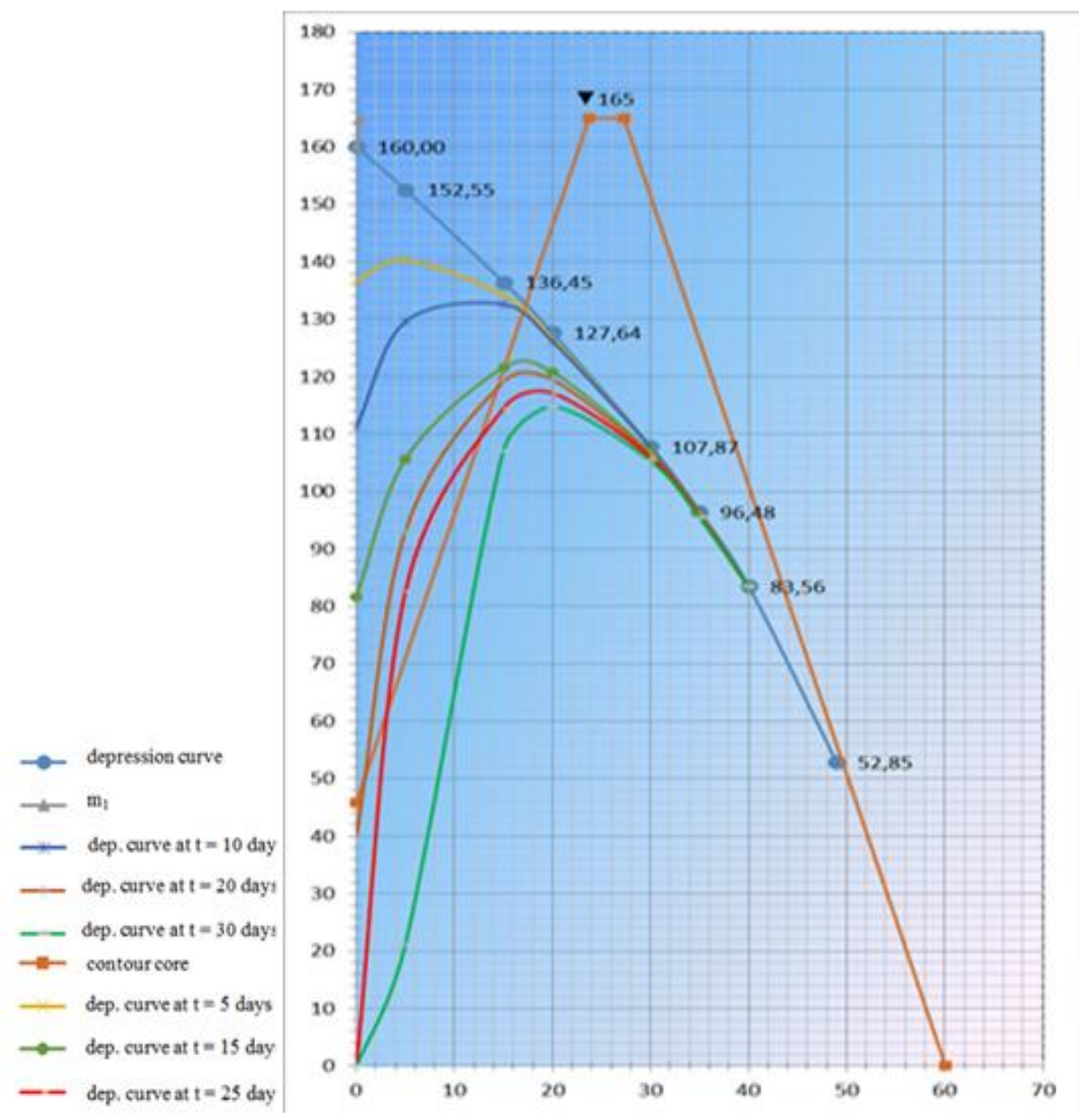

Fig. 4. Phreatic line for design condition for draw-off velocity $v=3.5 \mathrm{~m} /$ day and water yield factor $\mu=0.032$

Based on data in Tables 1- 4, phreatic lines in the core were constructed under conditions of unsteady filtration for various water yield factors and draw-off velocities of the water reservoir, which are partially given in 'figures 1-4'.

As seen from Table 1 and Fig. 1, the changes in the phreatic line after 5 days and 10 days are small. Further drainage of the water reservoir with velocity $2.5 \mathrm{~m} /$ dah increase filtration pressure, when $\mathrm{t}=15$ days $\Delta \mathrm{H}=17 \mathrm{~m}$, when $\mathrm{t}=20$ days $\Delta \mathrm{H}=28 \mathrm{~m}$, when $\mathrm{t}=25$ days $\Delta \mathrm{H}=53 \mathrm{~m}$, when $\mathrm{t}=30$ days $\Delta \mathrm{H}=100 \mathrm{~m}$, i.e., there is a significant delay of the phreatic line from water level in the water reservoir.

The increase of water yield coefficient from $\mu=0.028$ (Fig. 1) to $\mu=0.03$ (Fig. 2) at similar draw-off velocity $\mathrm{v}=2.5 \mathrm{~m} /$ day results in the decrease of filtration pressure from $\Delta \mathrm{H}=100 \mathrm{~m}$ to $\Delta \mathrm{H}=90 \mathrm{~m}$ at $\mathrm{t}=30$ days.

The increase of draw-off velocity from $3.5 \mathrm{~m}$ /day to $5 \mathrm{~m}$ /day increases the filtration pressure $\Delta \mathrm{H}$ (Figure 3 and 4 ).

All this proves the increase of the intensity of unsteady filtration depending on the increase of water reservoir draw-off velocity increase, which may result in the damage to the stability of the upper slope and its lining 


\section{Conclusions}

Calculation results on determining phreatic line position in the core of design dam of Tupolang water reservoir shows the following: the height of seepage into the lower edge is at $\nabla 850.50 \mathrm{~m}$. According to filtration study data, given by institute "Uzgiprovodhoz" in 1981 (using EGDA device), it is at $\nabla 851 \mathrm{~m}$. The difference is $0.5 \mathrm{~m}$, which proves the accuracy of the chosen design method. The increase of the velocity and time of water reservoir draw-off results in the increase of water yield factor, and its decrease result in the increase of filtration pressure. The increase of filtration pressure, in turn, facilitates the increase of the intensity of unsteady filtration in the core of the Tupolang dam.

\section{References}

1. Nedriga V.P. and others. Hydraulic structures. Designer's manual. "Stroyizdat". p.543, Moscow, (1983)

2. Fayziyev X. The study of unsteady filtration in the upper prizm of dams with horizontal drainage. All-Union scientific-technical conference of young specialists «HPS construction in upland conditions». Presentation thesises. Moscow. (1982)

3. Fayziyev X. Design of unsteady filtration in dams with core and horizontal drainage at the upper quoin. Degest: The study of tailing pits and industrial waste flow detention basins. «VODGEO» institute proceeding. Moscow, (1982)

4. Bakiev M.R., Rakhmatullaev S., Huneau F., Le Coustumer P., Motelika-Henio M. Facts and perspectives of water reservoirs in Central Asia: A special focus on Uzbekistan. International journal water. Switzerland, (2010)

5. Bakiev M.R., Rakhmatullaev S., Huneau F., Le Coustumer P., Motelika-Henio. Sedimentation of reservoirs in Uzbekistan: a case study of the Akdarya reservoir, Zerafshan River Basin, Proceedings of the Workshop held at Hyderabad, India, (2009)

6. Rakhmatullaev, S., Huneau, F., Celle-Jeanton, H., ...Motelica-Heino, M., Bakiev, M. Water reservoirs, irrigation and sedimentation in Central Asia: A first-cut assessment for Uzbekistan. Environmental Earth Sciences, 68(4), pp.985-998, (2013)

7. A.Hamidov, U.Kasymov, A.Salokhiddinov, M.Khamidov. How can intentionality and path dependence explain change in water-management institutions in Uzbekistan. International Journal of the Commons, 14(1), pp. 16-29. DOI: https://doi.org/10.5334/ijc.947.

8. Andrea Castelleti, Francesca Pianosi, Rodolfo Soncini-Sessa. Water reservoir control economic, social and environmental constraints. Sience Direst. Automatica 2008, 44(6). pp.1595-1607, (2008)

9. Pradham Deepa; Ancer Tihomir, Dryan, RossG; Harris, Michael. Management of Water Reservoirs (Embungs) in West Timor, Indonesia. Australian Agricultural and Recourse Economics Society (AARES) $>$ AARES Conferences $>2009$. Conference (52 rd), February 11-13, 2009, Cairns, Australia. doi 10.22004/ag.econ.48052.

10. Bakiev M.R., Hrupin R.V., Babajanov, K.K. Improving the structural elements of earth-fill dams, providing their operational reliability and safety. Monography. p.160 Tashkent, (2014)

11. Bakiev, M.R. Analysis of problems of reliable and safe operation of earth-fill dam of water reservoir hydrosystems. Irrigation and melioration journal. pp.14-18, Tashkent, (2018)

12. Wan-zhen Song, Yun-zhong Jiang, Xiao-hui Lei, Hao Wang, Dong-cai Shu. Annual runoff and flood regime trend analysis and the relation with reservoirs in the Sanchahe River Basin. Quaternary International. China, pp. 380-387 
13. Veksler A.B., Ivanshintsov D.A., Stefanishit D.V. Reliability, social and environmental safety of hydraulic objects: risk evaluation and taking decisions. St.Petersburg. p.552, (2002)

14. Bakiev M.R., Kirillova E.I., Hujaqulov R. Safety of hydraulic structures, p.110, Tashkent. (2008)

15. Demetris Kontsoyiannis. Reliability Concepts in Reservoir Design (sw-776). https//www.researchgate.net/publication/2296761152005/ doi:10.1002/047147844x.sw776.

16. Bakiev M.R., Kirillova E.I., Talipov Sh.G., Ernazarov N.Sh. Operational reliability and safety of hydraulic structures. p.131, Tashkent, (2016)

17. Discharge hydraulic structures (discharge, spillways). Design regulations. Standartinform. p.120, Moscow, (2017)

18. B Bondarenko, V.L., Belokonev, E.N. To the problem of providing hydraulic safety for spillway and discharge structures. Hydrodynamics and Hydrotechnics. Russia. №1. pp.86-92.

19. Volosuhin V.A., Belokonev E.N. About carrying capacity of shaft spillway in Neberdjaev water reservoir in Krasnoyarsk Kray. PNIPU Bulletin. Construction and architecture. № 1. pp.69-84, Russia, (2013)

20. Fayziev Kh, Baymatov Sh., Rakhimov Sh., Khodjiev T., Khodjiev I. The Calculation of Unsteady Filtration in Uniform Ground Dams Taking onto Account Filtration Animatropic Grounds. International Journal of Advanced Research in Science, Engineering and Technology. 6, (7), (2019). pp. 10284-10288

21. Yangiev A.A., Gapparov F.A., Adjimuratov D.S. Filtration process in earth fill dam body and its chemical effect on piezometers. E3S Web of Conferences 97, 04041 (2019)

22. Yangiev, A.A., Bakiev, M.R., Muratov, O.A., Choriev, J.M., Djabbarova, S. Service life of hydraulic structure reinforced concrete elements according to protective layer carbonization criteria Journal of Physics: Conference Series 1425(1), (2020) 